\title{
Exergetic Investigation of the Effects of Superheating and Subcooling on Performance of a Vapor Compression Refrigeration Cycle
}

\author{
İbrahim Karaçaylı** (D), Erdoğan Şimşek² \\ 'Ege University, Ege High Vocational School, Air Conditioning and Refrigeration Technology Program, Turkey \\ 2Cukurova University, Adana High Vocational School, Air Conditioning and Refrigeration Technology Program, Turkey
}

\begin{abstract}
The aim of this study is to investigate the effects of superheating and subcooling values on the cooling performance of a vapor compression refrigeration cycle. For this purpose, a refrigeration cycle with cooling capacity of $8 \mathrm{~kW}$ using R404A was examined by changing superheating and subcooling values. Energy, exergy and entropy balances were applied for evaporation and condensation temperatures of $0^{\circ} \mathrm{C}$ and $45^{\circ} \mathrm{C}$, respectively. The coefficient of cooling performance (COP), the amount of energy transfer, rate of exergy destruction and rational exergy efficiency of each components (evaporator, compressor, condenser and expansion valve) and the whole system were determined. The compressor work, coefficient of performance and second law efficiency increased by $0.7 \%, 1.61 \%$ and $1.56 \%$, respectively, per one-degree increment of superheating in the evaporator.
\end{abstract}

Keywords: Exergy, Exergy destruction, Refrigeration cycle, Superheating, Subcooling.

\section{INTORDUCTION}

Simple vapor compression refrigeration system is generally preferred for refrigeration and air conditioning systems. The refrigerant leaves from evaporator and enters compressor as a saturated vapor. Also, in the condenser unit, the refrigerant is completely condensed to saturated liquid [1]. In practice, however, the refrigerant enters the compressor as superheated vapor and enters the throttle valve as compressed liquid. Thus, for design of a vapor compression refrigeration system, the refrigerant in the exit of the condenser and evaporator are often considered as subcooled and superheated, respectively [2]. And superheating and subcooling procedures are applied to improve performance of the refrigeration system [3].

Bilgili et. al. (2017) performed thermodynamic analysis of an inter-city bus air conditioner using R600 as working fluid. Superheating and subcooling temperature values defined as $10^{\circ} \mathrm{C}$ for exergy efficiency and exergy destructions of the bus air conditioning system [4]. Yulmaz and Aktaș (2019) investigated ejector refrigeration (ER) system using exhaust waste heat of a heavy vehicle engine using R134a and R245fa. In order to determine the performance coefficient, engineering equation solver software was used and subcooling and superheating were taken as $1{ }^{\circ} \mathrm{C}[5]$.
Beşer and Mobedi (1999) analyzed the effect of subcooling the refrigerant at the exit of the condenser in a simple vapor compression cycle on the energetic performance for different refrigerants, such as R407C, R134a and R22 [6]. Kizllkan et. al. (2006) examined subcooling and superheating heat exchangers of vapor compressed refrigeration system for R22 and R407c. The optimum areas of subcooling and superheating heat exchangers determined in relation to economics and working performance [7]. Yan et. al. (2019) theoretically evaluated a novel vapor compression refrigeration cycle with subcooler for freezer applications to increase cooling effect and the COP of the system [8].

Different applications of the refrigeration cycle have widely examined in literature. Chen et. al. (2019) integrated solar absorption-subcooling cycle to vapor compression refrigeration cycle to enhance the cooling capacity [9]. Bellos and Tzivanidis (2019) compared transcritical $\mathrm{CO}_{2}$ refrigeration systems to conventional system. And COP enhancement of the configuration which contain mechanical subcooling was $75.8 \%$ compared to without subcooling cycle [10]. Wang and Zhang (2019) modeled parametrically simple transcritical refrigeration cycles using R744 as refrigerant with different subcooling methods. They applied energy, exergy and economic analyses to the models with different subcooling methods in order to investigate the effect of the ambient
* Corresponding authour

Email: ibrahim.karacayli@ege.edu.tr 
temperature on the performance [11].

In the literature, it was widely mentioned that subcooling of the refrigerant at the condenser outlet improved the performance. However, it was not stated that in which range of the subcooling value increases the system performance. Besides, the effect of the superheating at the evaporator outlet on cooling performance was not investigated in literature. In the present study, energy and exergy analyses were applied to a vapor compression refrigeration cycle working with R404A. The main purpose of this paper is to emphasize the importance of the effect of the subcooling and superheating on the system performance. Thus, besides energy transfer rate and exergy destruction rate within the all components and entire cycle, $\mathrm{COP}$ of cycle for cooling and rational exergy efficiency of all components and whole cycle were determined from energy and exergy analyses.

\section{MATERIAL AND METHODS}

A single-stage vapor compression refrigeration cycle was considered. Most of refrigeration and heat pump systems use this cycle to transfer heat from one medium to another to obtain heating or cooling. There are four main elements: an evaporator, a compressor, a condenser and an expansion valve. R404A is selected as working fluid. Schematic representation of the refrigeration cycle and logP-h diagram of that cycle are shown Figure 1.
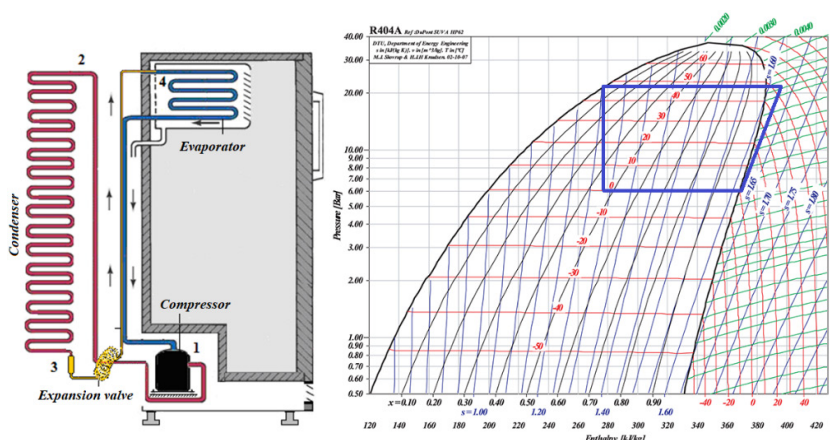

Figure 1. The refrigeration cycle and logP-h diagram for R404A

Technical specifications of the refrigeration cycle to be considered in the calculations for energy and exergy analyses are listed in Table 1.

Table 1. Technical specifications of the cycle

\begin{tabular}{|c|c|}
\hline Definition & Properties \\
\hline Refrigerant & R404A \\
\hline Cooling capacity & $8 \mathrm{~kW}$ \\
\hline Evaporation temperature & $0^{\circ} \mathrm{C}$ \\
\hline Condensation temperature & $45^{\circ} \mathrm{C}$ \\
\hline Evaporator tube diameter & $5 / 8^{\prime \prime}$ \\
\hline Condenser tube diameter & $3 / 8^{\prime \prime}$ \\
\hline Tube / Fin material & Copper / Aluminum \\
\hline
\end{tabular}

Both superheating and subcooling values were gradually increased from $1^{\circ} \mathrm{C}$ to $8^{\circ} \mathrm{C}$ and to $9^{\circ} \mathrm{C}$, respectively. The evaporation and condensation temperatures were kept constant at $0^{\circ} \mathrm{C}$ and $45^{\circ} \mathrm{C}$, respectively.

\section{THERMODYNAMICS ANALYSIS}

To calculate the energy transfer rate, exergy destruction rate, the entropy generation rate and the exergy efficiency of each components of the refrigeration cycle, energy and exergy balances were applied to the cycle. In the calculations, the following assumptions were made:

- All processes in the cycle are assumed as steady state and no frictional loss throughout the cycle.

- The change of kinetic and potential energies of the entire system are zero and there are no chemical, magnetic and nuclear reactions.

- Heat transfer takes place only in the condenser and the evaporator units so the compression and expansion processes are adiabatic.

- The work transfer in the expansion valve is neglected.

- The mechanical and electrical efficiency of the compressor are taken as $70 \%$ and $75 \%$, respectively.

- Evaporation and condensation processes occur at a constant pressure.

Energy balance can be defined as the difference between inlet and outlet energy transfer rate by heat, work and mass equals to the net energy change in total energy of the system $[12,13]$.

$$
\dot{E}_{\text {heat }, \text { in }}+\dot{E}_{\text {mass,in }}-\dot{E}_{\text {work }, \text { out }}=\Delta \dot{E}_{\text {system }}
$$

This equation is also called as the first law of thermodynamics or the energy conservation law. From this equation, rate of heat transfers in the evaporator and the condenser units and work transfer in the compressor unit are determined. Since the rate of removing heat from cold medium or the evaporator capacity is known, the refrigerant mass flowrate can be determined as follow.

$$
\dot{m}_{r}=\dot{Q}_{e} /\left(h_{1}-h_{4}\right)
$$

Following equation was used to define the isentropic efficiency of the compressor [14].

$$
\eta_{i}=0,874-0,0135 P_{c} / P_{e}
$$

By the definition of the isentropic efficiency of the compressor, enthalpy of the compressor outlet is obtained.

$$
h_{2}=h_{1}+\frac{\left(h_{2 i}-h_{1}\right)}{\eta_{i}}
$$

where $\boldsymbol{h}_{2 \mathrm{i}}$ is the enthalpy at the outlet of the compressor in the case of isentropic compression process. The COP for cooling is the heat removing from refrigerated space divided by required work.

$$
\mathrm{COP}=\frac{\dot{Q}_{e}}{\dot{W}_{\text {elc }}}=\frac{h_{1}-h_{4}}{h_{2}-h_{1}} \cdot \eta_{m e c} \cdot \eta_{\text {elc }}
$$


The exergy destruction rate equals to exergy rate by net mass input, net heat input and net work output [15].

$$
\dot{X}_{\text {dest }}=\dot{X}_{\text {mass }, \text { in }}+\dot{X}_{\text {heat }, \text { in }}-\dot{X}_{\text {work,out }}
$$

The flow exergy is evaluated as [15]:

$$
\varepsilon=\left(h-h_{0}\right)-T_{0}\left(s-s_{0}\right)
$$

The general exergy destruction rate is

$$
\dot{X}_{\text {dest }}=\dot{m}\left(\varepsilon_{\text {in }}-\varepsilon_{\text {out }}\right)+\left(1-\frac{T_{0}}{T}\right) \dot{Q}_{\text {in }}-\dot{W}_{\text {out }}
$$

The second law or exergy efficiency

$$
\eta_{I I}=\frac{C O P}{\operatorname{COP}_{\text {Carnot }}}
$$

The rational exergy is taken [13].

$$
\psi=\frac{\dot{X}_{\text {dest }, \text { out }}}{\dot{X}_{\text {cons,in }}}
$$

The rate of energy transfers, the rate of exergy destruction and the rational exergy efficiency equations are summarized in Table 2. The dead state properties are taken at the temperature of $10^{\circ} \mathrm{C}$ and pressure of $101.3 \mathrm{kPa}$.

Table 2. The equations of the energy transfer rate, exergy destruction rate and the exergy efficiency

\begin{tabular}{llll}
\hline Component & Energy transfer rate & Exergy destruction rate & Exergy efficiency \\
\hline Evaporator & $\dot{Q}_{e}=\dot{m}_{r}\left(h_{1}-h_{4}\right)$ & $\dot{X}_{e}=\dot{m}_{r}\left(\varepsilon_{4}-\varepsilon_{1}\right)+\left(1-\frac{T_{0}}{T_{e}}\right) \dot{Q}_{e}$ & $\psi_{e}=\left(1-\frac{T_{o}}{T_{\text {evap }}}\right) \cdot \frac{h_{4}-h_{1}}{\varepsilon_{4}-\varepsilon_{1}}$ \\
Compressor & $\dot{W}_{c o m}=\dot{m}_{r}\left(h_{2}-h_{1}\right)$ & $\dot{X}_{c o m}=\dot{m}_{r}\left(\varepsilon_{1}-\varepsilon_{2}\right)+\dot{W}_{c o m}$ & $\psi_{c o m}=\frac{\varepsilon_{2}-\varepsilon_{1}}{h_{2}-h_{1}}$ \\
$\begin{array}{l}\text { Expansion } \\
\text { valve }\end{array}$ & $h_{3}=h_{4}$ & $\dot{X}_{\text {exp }}=\dot{m}_{r}\left(\varepsilon_{3}-\varepsilon_{4}\right)$ & $\psi_{\text {exp }}=\frac{\varepsilon_{4}}{\varepsilon_{3}}$ \\
Condenser & $\dot{Q}_{c}=\dot{m}_{r}\left(h_{2}-h_{3}\right)$ & $\dot{X}_{c}=\dot{m}_{r}\left(\varepsilon_{2}-\varepsilon_{3}\right)-\left(1-\frac{T_{0}}{T_{c}}\right) \dot{Q}_{c}$ & $\psi_{c}=\left(1-\frac{T_{o}}{T_{c o n d}}\right) \cdot \frac{h_{2}-h_{3}}{\varepsilon_{2}-\varepsilon_{3}}$ \\
$\begin{array}{l}\text { Refrigeration } \\
\text { cycle }\end{array}$ & $\dot{Q}_{e}+\dot{W}_{c o m}-\dot{Q}_{c}=0$ & $\dot{X}_{r c}=\left(1-\frac{T_{0}}{T_{e}}\right) \dot{Q}_{e}-\left(1-\frac{T_{0}}{T_{c}}\right) \dot{Q}_{c}+\dot{W}_{\text {elc }}$ & $\psi_{r c}=\frac{\dot{X}_{\dot{Q}_{c}}-\dot{X}_{\dot{Q}_{e}}}{\dot{W}_{\text {elc }}}$ \\
\hline
\end{tabular}

\section{RESULTS AND DISCUSSIONS}

The energy and exergy analyses results of refrigeration cycle using R404A at the superheating and subcooling values of and are summarized in Table 3. In this conditions, the exergy efficiency of entire system and the COP for cooling were obtained as $35.1 \%$ and 3.81, respectively. Besides, the maximum and minimum exergy destructions were recorded in the expansion valve as $0.43 \mathrm{~kW}$ and in the evaporator unit as $8.62 \mathrm{~W}$, respectively.

COP for cooling increased by increasing the superheating and subcooling values, for instance COP at lowest and highest superheating and subcooling values were computed as 1.787 and 2.038, respectively. Effects of superheating and subcooling on the coefficient of cooling performance is shown in Figure 2. According to graphs, the effect of subcooling in improvement of COP is more significant to superheating.

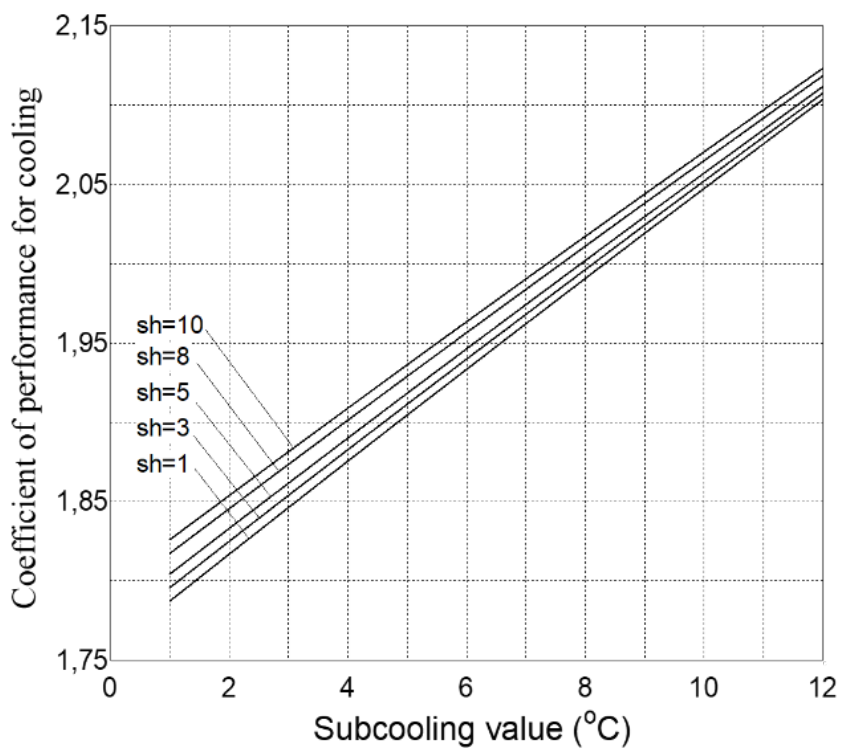

Figure 2. Variations of COP for cooling with superheating and subcooling values.

The exergy destruction in whole cycle was low at the smallest superheating and at the highest subcooling values. Effects of superheating and subcooling on the exergy destruction in the refrigeration cycle is plotted in Figure 3. The minimum and maximum exergy destruction in cycle were obtained as 2971.0 W at $s h=1^{\circ} \mathrm{C}, s c=9^{\circ} \mathrm{C}$ and $3263.1 \mathrm{~W}$ at $s h=8^{\circ} \mathrm{C}, s c=1^{\circ} \mathrm{C}$ respectively.

In the compressor, the amount of exergy destructions at $\mathrm{sh}=1^{\circ} \mathrm{C}$ and at $\mathrm{sh}=8^{\circ} \mathrm{C}$ were $360.26 \mathrm{~W}$ and $371.33 \mathrm{~W}$, respectively. There was no change in the exergy destruction in compressor for different subcooling values. In addition,

\begin{tabular}{|c|c|c|c|c|c|c|c|}
\hline Location & $\left({ }^{\circ} \mathrm{C}\right)$ & $(\mathrm{kPa})$ & $(\mathrm{kg} / \mathrm{s})$ & $(\mathrm{kJ} / \mathrm{kg})$ & $(\mathrm{kJ} / \mathrm{kgK})$ & $(\mathrm{kJ} / \mathrm{kg})$ & $(\mathrm{kW})$ \\
\hline 0 & 10 & 101.3 & - & 237.2 & 1.02525 & 0 & - \\
\hline 1 & 5 & 604 & 0.0826 & 223.1 & 0.83197 & 40.66 & 3.3584 \\
\hline 2 & 58.8 & 2063 & 0.0826 & 253.2 & 0.84765 & 66.30 & 5.4754 \\
\hline 3 & 37 & 2063 & 0.0826 & 108.4 & 0.39337 & 50.17 & 4.1433 \\
\hline 4 & 0 & 604 & 0.0826 & 108.4 & 0.41174 & 44.97 & 3.7138 \\
\hline \multicolumn{2}{|c|}{ Component } & \multicolumn{2}{|c|}{ Energy transfer rate } & \multicolumn{2}{|c|}{ Exergy destruction rate } & \multicolumn{2}{|c|}{ Exergy efficiency } \\
\hline \multicolumn{2}{|c|}{ Evaporator } & \multicolumn{2}{|c|}{$9.472 \mathrm{~kW}$} & \multicolumn{2}{|c|}{$8.621 \mathrm{~W}$} & \multicolumn{2}{|c|}{$97.6 \%$} \\
\hline \multicolumn{2}{|c|}{ Compressor } & \multicolumn{2}{|c|}{$2.484 \mathrm{~kW}$} & \multicolumn{2}{|c|}{$366.8 \mathrm{~W}$} & \multicolumn{2}{|c|}{$85.2 \%$} \\
\hline \multicolumn{2}{|c|}{ Expansion valve } & \multicolumn{2}{|c|}{-} & \multicolumn{2}{|c|}{$429.5 \mathrm{~W}$} & \multicolumn{2}{|c|}{$89.6 \%$} \\
\hline \multicolumn{2}{|c|}{ Condenser } & \multicolumn{2}{|c|}{$11.956 \mathrm{~kW}$} & \multicolumn{2}{|c|}{$16.92 \mathrm{~W}$} & \multicolumn{2}{|c|}{$98.7 \%$} \\
\hline \multicolumn{2}{|c|}{ Refrigeration cycle } & \multicolumn{2}{|c|}{-} & \multicolumn{2}{|c|}{$3069 \mathrm{~W}$} & \multicolumn{2}{|c|}{$35.1 \%$} \\
\hline
\end{tabular}
effects of superheating and subcooling on the exergy destruction in evaporator, condenser and expansion valve are illustrated in Figure 4, 5 and 6, respectively.

Table 3. The energy and exergy analyses results at and . 


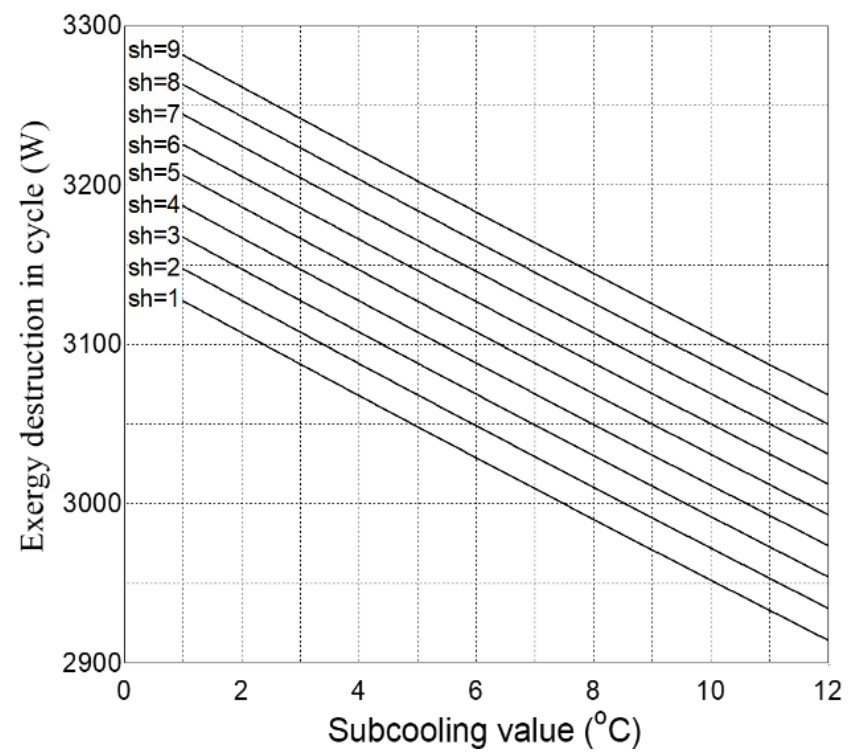

Figure 3. Variations of total exergy destruction with superheating and subcooling values.

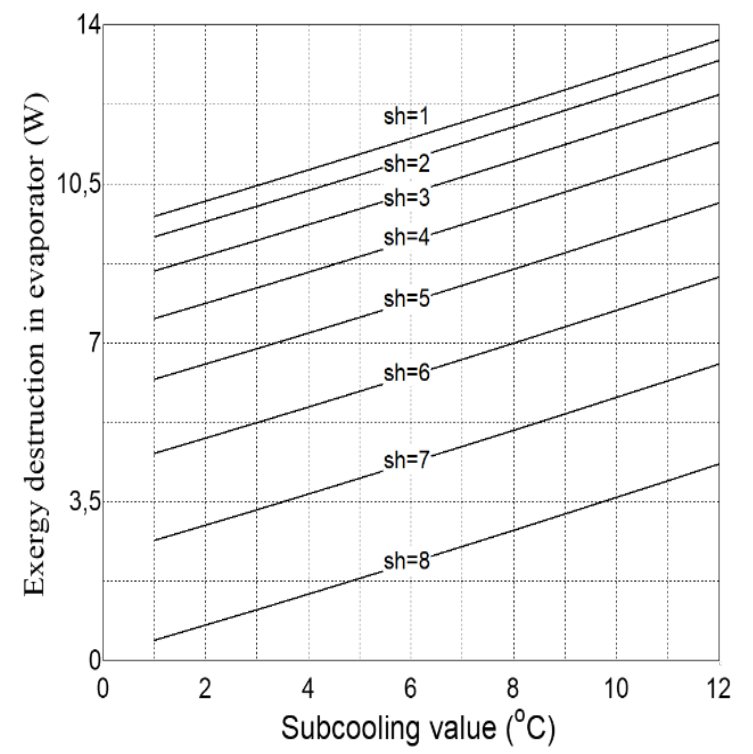

Figure 4. Variations of exergy destruction in evaporator with superheating and subcooling values.

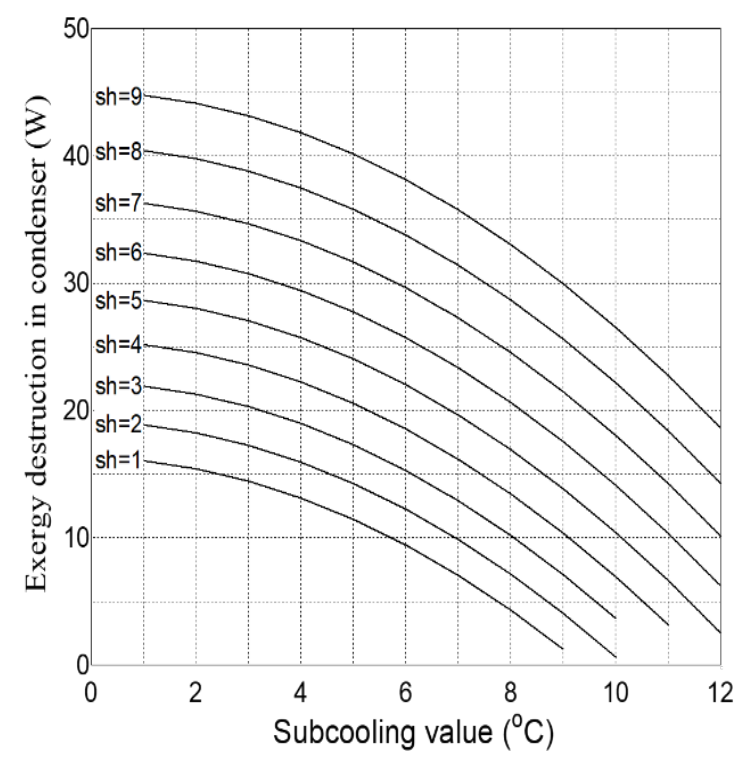

Figure 5. Variations of exergy destruction in condenser with superheating and subcooling values.

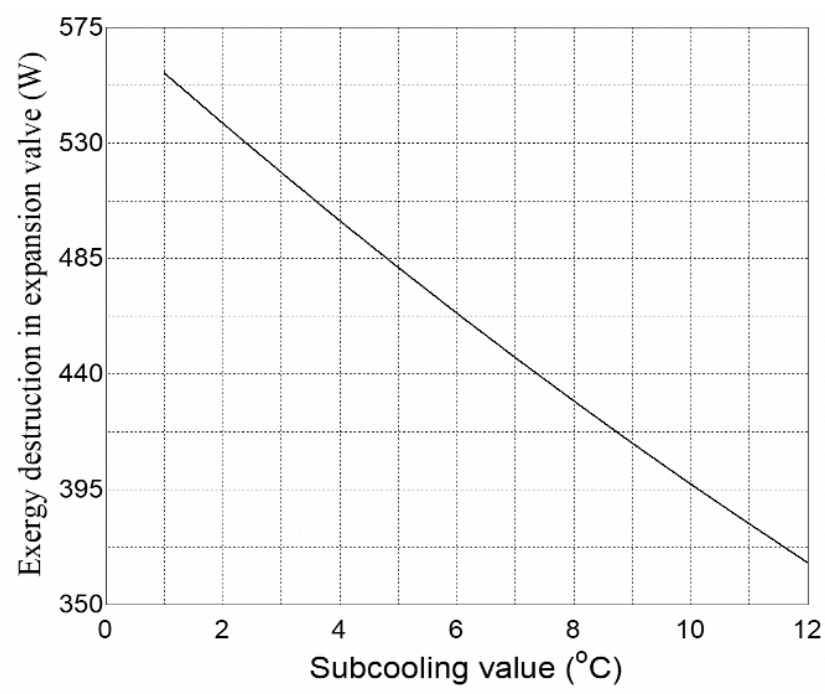

Figure 6. Variations of exergy destruction in expansion valve with subcooling values.

The exergy destruction in evaporator increased when superheating decreased and subcooling increased. The minimum exergy destruction in the evaporator was computed at and it increased from $0.454 \mathrm{~W}$ to $3.237 \mathrm{~W}$ when the superheating increased from $1^{\circ} \mathrm{C}$ to $9^{\circ} \mathrm{C}$. Otherwise, the exergy destruction in condenser increased when superheating increased and subcooling decreased. The minimum exergy destruction in the condenser was obtained at and it decreased from 16.05 W to $1.239 \mathrm{~W}$ when the superheating increased from $1^{\circ} \mathrm{C}$ to $9^{\circ} \mathrm{C}$. In the expansion valve exergy destruction was depends on subcooling and as subcooling value increases from $1^{\circ} \mathrm{C}$ to $9^{\circ} \mathrm{C}$, exergy destruction has decreased from 557.4 W to $413.0 \mathrm{~W}$.

Figure 7 indicates the effect of the superheating and subcooling on the rational exergy efficiency of evaporator. As shown in this figure, when the subcooling values increased, the rational exergy efficiency of evaporator decreased linearly from $96.85 \%$ to $96.43 \%$ at and when the superheating values increased, rational exergy efficiency increased from $96.85 \%$ to $99.86 \%$ at .

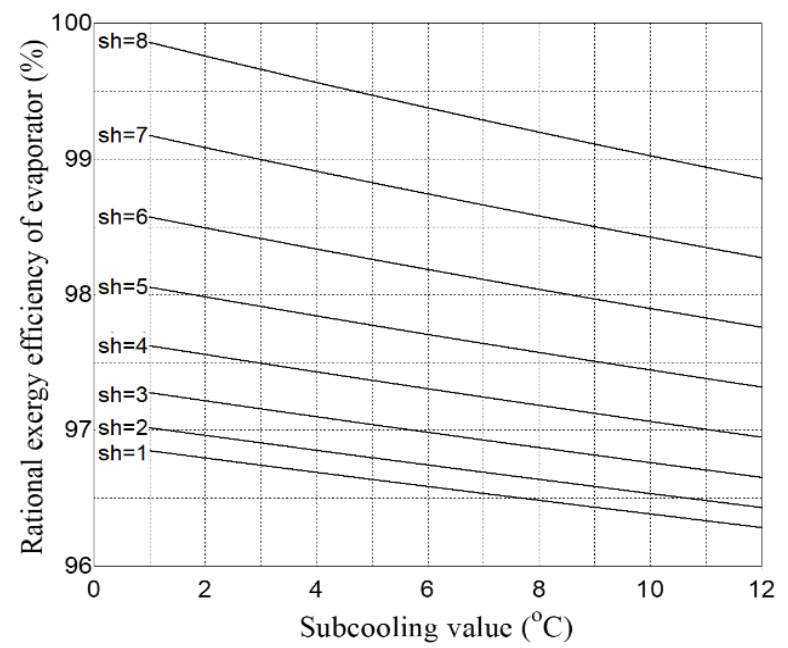

Figure 7. Variations of exergy efficiency of evaporator with superheating and subcooling values. 
Also, Figure 8 illustrates the effects of the superheating and subcooling on the rational exergy efficiency of condenser. According to this figure, the rational exergy efficiency of condenser decreased by the superheating value from $98.65 \%$ to $96.85 \%$ at and increased by the subcooling value from $98.65 \%$ to $99.90 \%$ at .

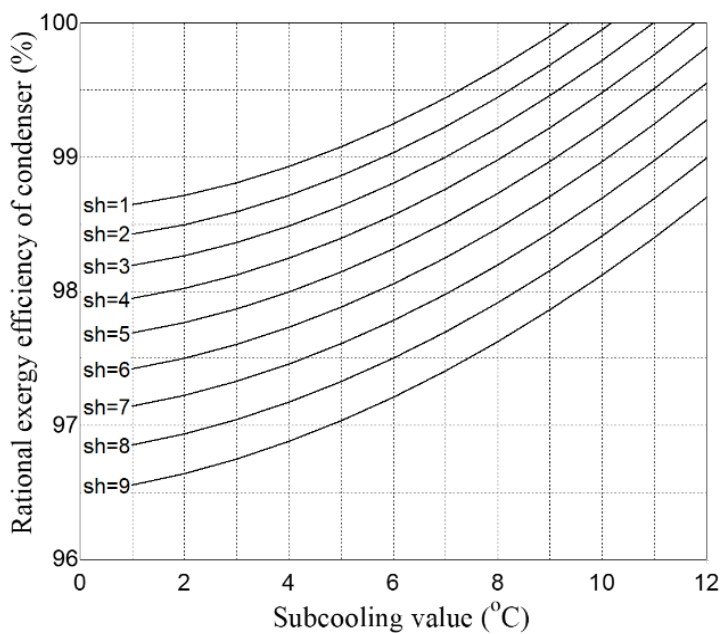

Figure 8. Variations of exergy efficiency of condenser with superheating and subcooling values.

Further, the effects of the superheating and subcooling on the rational exergy efficiency of expansion valve is shown in Figure 9. Variations in subcooling value caused a significant change in the rational exergy efficiency of expansion valve. For example, the rational exergy increased from $86.84 \%$ to $90.00 \%$. On the other hand, variations in superheating value didn't cause any change.

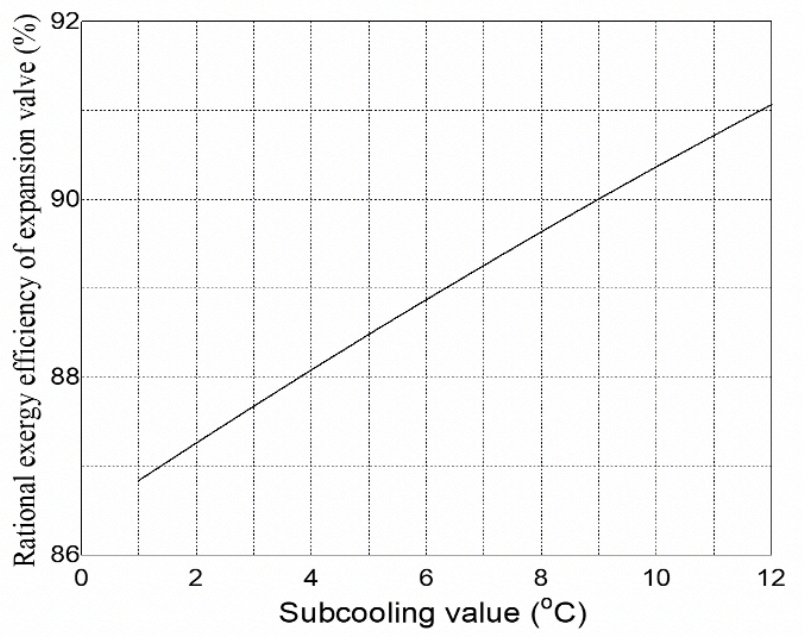

Figure 9. Variations of exergy efficiency of expansion valve with subcooling values

Furthermore, variation of the rational exergy efficiency of refrigeration cycle with the superheating and subcooling is presented in Figure 10. As can be seen in this figure, the effect of the subcooling on the exergy efficiency of whole cycle was more considerable than the effect of the superheating. For instance, the exergy efficiency linearly increased with subcooling value from $31.98 \%$ to $35.38 \%$ at, otherwise, the exergy efficiency linearly increased with superheating value from $31.98 \%$ to $32.42 \%$ at

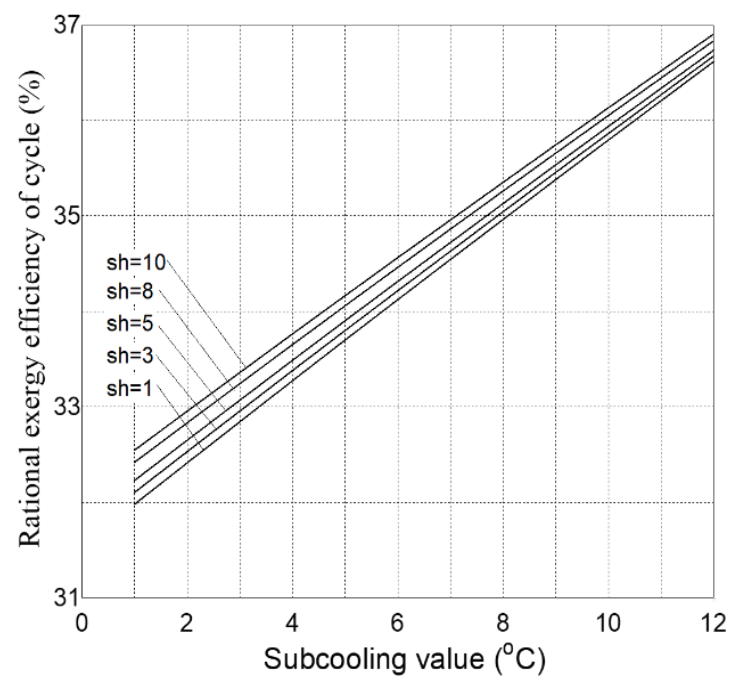

Figure 10. Variations of exergy efficiency of whole cycle with superheating and subcooling values

\section{CONCLUSIONS}

The superheating and the subcooling values were increased $1^{\circ} \mathrm{C}$ to $8^{\circ} \mathrm{C}$ and $9^{\circ} \mathrm{C}$, respectively under the same evaporation and condensation pressures. The effect of the superheating and the subcooling values on the performance of a refrigeration system using R404A is investigated.

The following main results are achieved from this study:

a) The compression work or the electrical consumption rate increased approximately $0.7 \%$ per $1^{\circ}$ increment in superheating and $\% 5$ for $8^{\circ}$ difference in superheating. In contrast, there has been no change in the rate of compression work for different subcooling values.

b) The COP increased by an average of 1.61 and 1.54, respectively, with a one-degree increase in superheating and subcooling.

c) The change in exergy destruction in the compressor was negligible for increase in superheating and subcooling values. The change in exergy destruction in entire system decreased by $1.03 \%$ and $1.06 \%$, respectively, per one-degree increment of superheating and subcooling.

d) Exergy efficiency increased by approximately $1.56 \%$ for each one-degree increase in both superheating and subcooling.

\section{NOMENCLATURE}

$\dot{E} \quad$ : Energy transfer rate $(k W)$

$h \quad:$ Specific enthalpy $(k J / k g)$

$\dot{m}$

: Mass flow rate $(\mathrm{kg} / \mathrm{s})$

$P$

: Absolute pressure $(\mathrm{kPa})$

$\dot{Q}$

: Heat transfer rate $(k W)$

$s$ 


\section{sc $\quad$ : Subcooling value $\left({ }^{\circ} \mathrm{C}\right.$ or $\left.K\right)$ \\ sh : Superheating value $\left({ }^{\circ} \mathrm{C}\right.$ or $\left.K\right)$ \\ $T \quad$ : Temperature $\left({ }^{\circ} \mathrm{C}\right.$ or $\left.\mathrm{K}\right)$ \\ $\dot{W} \quad$ : Work transfer rate or power $(k W)$ \\ $\dot{X} \quad$ : Exergy transfer rate $(\mathrm{kW})$}

\subsection{Greek symbols}

$\eta \quad$ : Efficiency (\%)

$\mu \quad$ : Dynamic viscosity of fluid $(\mathrm{kg} / \mathrm{m} \cdot \mathrm{s})$

$\psi \quad$ : Rational exergy efficiency (\%)

$\Delta \quad:$ Difference

\subsection{Subscripts}

$0 \quad$ : Dead state

$1,2, \ldots$ : Cycle locations

II : Second law

com : Compressor

c : Condenser or condensation

cons : Consumed

dest : Destroyed

e : Evaporator or evaporation

elc : Electrical

exp : Expansion valve

f : Saturated liquid phase

g : Saturated vapor phase

gen : Generation

in $\quad:$ Inlet

mec : Mechanical

rc : Refrigeration cycle

SC : Subcooling

sh : Superheating

out : Outlet

\section{Abbreviations}

COP : Coefficient of performance

\section{REFERENCES}

[1] Moran, M. J., Shapiro, H. N., Boettner, D. D., Bailey, M. B. (2010). Fundamentals of Engineering Thermodynamics. John Wiley \& Sons.

[2] Dingeç, H., Illeri, A. (1999). Thermoeconomic optimization of simple refrigerators. Int J Energy Research, 23(11): 949-962, DOI:10.1002/(SICI)1099-114X(199909)23:11<949::AID-ER531>3.0.CO;2-A
[3] Selbaş, R., Kızılkan, Ö., Şencan, A. (2006). Thermoeconomic optimization of subcooled and superheated vapor compression refrigeration cycle. Energy, 31(12): 2108-28, DOI:10.1016/j.energy.2005.10.015

[4] Bilgili, M., Cardak, E., Aktas, A. E. (2017). Thermodynamic analysis of bus air conditioner working with refrigerant R600a. European Mechanical Science 2017, 1(2): 69-75, DOI:10.26701/ems.321874.

[5] Yilmaz, A., Aktas, A. E. (2019). Comparative analysis of ejector refrigeration system powered with engine exhaust heat using R134a and R245fa. European Mechanical Science, 3(1): 13-17, DOI:10.26701/ ems.430831.

[6] Beşer, E.,Mobedi, M. (1999). Soğutma sistemlerinde soğutucu akışkanın aşırı soğutulmasının incelenmesi. IV. Ulusal Tesisat Mühendisliği Kongresi, Conference Proceedings, p.695-706.

[7] Kızılkan, Ö., Selbaş, R., Şencan, A. (2006). Buhar sıkıştırmalı soğutma sistemlerinde aşırı soğutma ve aşırı kızdırma etkisinin ısıl ekonomik açıdan incelenmesi. Gazi Üniversitesi Mühendislik Mimimarlık Fakültesi Dergisi, 21(2): 387-393.

[8] Yan, G., Liu, Y., Qian, S., Yu, J. (2019). Theoretical study on a vapor compression refrigeration system with cold storage for freezer applications. Applied Thermal Engineering, 160: 114091, DOI: 10.1016/j. applthermaleng.2019.114091.

[9] Chen, E., Li, Z., Yu, J., Xu, Y., Yu, Y. (2019). Experimental research of increased cooling output by dedicated subcooling. Applied Thermal Engineering, 154: 9-17, DOI: 10.1016/j.applthermaleng.2019.03.071.

[10] Bellos, E., Tzivanidis, C. (2019). A Comparative Study of CO2 Refrigeration Systems. Energy Conversion and Management: X, 1, Article 100002, DOI: 10.1016/j.ecmx.2018.100002.

[11] Wang, G.-B., Zhang, X.-R. (2019) Thermoeconomic optimization and comparison of the simple single-stage transcritical carbon dioxide vapor compression cycle with different subcooling methods for district heating and cooling. Energy Conversion and Management, 185: 740-757, DOl: 10.1016/j.enconman.2019.02.024.

[12] Cengel, Y. A., Boles, M. A. (2015). Thermodynamic: an engineering approach. McGraw-Hill Education, New York.

[13] Hepbasli, A., Akdemir, O. (2004). Energy and exergy analysis of a ground source (geothermal) heat pump system. Energy Conversion and Management, 45 (5): 737-753, DOl:10.1016/S01968904(03)00185-7.

[14] Brunin, O., Feidt, M., Hivet, B. (1997). Comparison of the working domains of some compression heat pumps and a compression-absorption heat pump. International Journal of Refrigeration, 20(5): 308-318, DOl:10.1016/S0140-7007(97)00025-X.

[15] Karaçaylı, I., Şimşek, E. (2019). Irreversibility analysis of a minibus air-conditioner for different condensation pressures. Çukurova University Journal of the Faculty of Engineering and Architecture, 34(2): 171-180, DOI:10.21605/cukurovaummfd.609114. 